\title{
Analisis Harga Pokok Produksi Usahatani Bawang Putih Berdasarkan Luas Lahan Desa Fatuneno Kabupaten Timor Tengah Utara
}

\author{
Marsela Kono ${ }^{\mathrm{a}}$, dan Boanerges Putra Sipayung ${ }^{\mathrm{b}}$ \\ ${ }^{a}$ Fakultas Pertanian, Universitas Timor, Kefamenanu,TTU - NTT, Indonesia.Email:marselakono95@gmail.com \\ ${ }^{b}$ Fakultas Pertanian, Universitas Timor, Kefamenanu,TTU - NTT, Indonesia.Email: sipayung.boanerges@gmail.com
}

\section{Article Info}

Article history:

Received 27 Desember 2019

Received in revised form 3 Januari 2020

Accepted 9 Januari 2020

DOI:

https://doi.org/10.32938/ag.v5i1.902

Keywords:

Usaha Tani

Harga Pokok Produksi

Bawang Putih

\section{Abstrak}

Perhitungan harga pokok produksi penting untuk mengetahui kondisi harga dari bawang putih. Penelitian ini bertujuan mengetahui harga pokok produksi dan keuntungan relatif yang diperoleh petani bawang putih Di Desa Fatuneno Kabupaten Timor Tengah Utara. Penelitian dilakukan dari bulan April 2019 sampai bulan Agustus 2019. Metode yang digunakan dalam penelitian ini metode deskriptif kuantitatif. Hasil analisis menunjukkan bahwa harga pokok produksi berdasarkan luas lahan terkecil Rp. 78.971, dan luas lahan terbesar Rp.28.921, ini lebih tinggi dari perhitungan petani untuk luas lahan terkecil sebesar Rp 20.301 luas lahan terbesar Rp 13.242. Rasio keuntungan usahatani bawang putih di desa Fatuneno dengan luas lahan terkecil sebesar 1,48 dan luas lahan terbesar 2,27, dengan rata-rata R/C rasio sebesar 1,76

\section{Pendahuluan}

Permintaan Bawang putih (Allium sativum L) terus meningkat sejalan dengan pertumbuhan jumlah penduduk, perkembangan ekonomi ke arah yang lebih baik dan meningkatnya pengetahuan masyarakat terhadap manfaatnya. Lokasi pengembangan tanaman bawang putih di Indonesia hanya terdapat pada beberapa wilayah diantaranya Bali \& Nusa Tenggara, Jawa, dan Sumatera.

Salah satu kabupaten di NTT yang terus menggalakkan usahatani bawang putih yakni Kabupaten Timor Tengah Utara (TTU), dimana Pemerintah Kabupaten Timor Tengah Utara terus mengupayakan daerah-daerah yan berpontensi untuk pengembangan bawang putih. Daerah yang berpotensi adalah Kecamatan Miomaffo Barat, yang kondisi iklimnya cocok untuk pertumbuhan tanaman bawang putih (ketinggian 700 - 1100 meter di atas permukaan laut (M dpl) dengan suhu rata-rata $20-25$ derajat Celcius dan memiliki curah hujan ratarata $1200-2400$ mili meter per tahun serta menghendaki tekstur tanah yan gembur dan subur) dan juga bagi masyarakatnya usahatani bawang putih telah dilakukan secara turun-temurun. Produksi bawang putih di Kecamatan Miomaffo Barat Kabupaten Timor Tengah Utara sangat berfluktuasi di setiap tahun, dari data yang diperoleh 3 tahun terakhir yaitu pada tahun 2014 menghasilkan 8 ton bawang putih, tahun 2015 menghasilkan 14 ton, dan tahun 2016 menghasilkan 5,6 ton (BPS TTU, 2017)

Harga pokok produksi adalah semua biaya yang terjadi dalam rangka pembelian faktor-faktor produksi dalam pembuatan produk. Dalam pendekatan full costing harga pokok produk akan sama dengan jumlah dan komponennya dengan biaya produksi (Samryn,2002). Carter (2009) harga pokok produks terdiri dari tiga elemen biaya, yaitu: bahan baku langsung, tenaga kerja langsung dan overhead pabrik. Harga pokok produksi usahatani bawang putih merupakan total biaya yang dikeluarkan oleh petani untuk memproduksi bawang putih dalam suatu proses budidaya pada satu musim tanam. Petani bawang putih sebaga produsen yang memproduksi bawang putih juga berorientasi pada laba,sehingga tidak terlepas dari masalah pencapaian laba, dan pengembalian modal, serta perhitungan biaya yang telah dikeluarkan untuk membeli benih bawang putih Perhitungan harga pokok produksi perlu dilakukan untuk mengetahui berapa biaya yang dikeluarkan oleh petani selama melakukan kegiatan usahatan sehingga petani mengetahui apakah harga yang diterima atas penjualan hasi panennya itu menguntungkan atau tidak.

Secara umum petani di Kecamatan Miomaffo Barat merupakan petani tradisional yang masih berpendidikan rendah. Petani tradisional yang terika dengan sosial budaya cenderung tidak memisahkan biaya kehidupan sehari-har dengan biaya produksi dari usaha taninya. Penetapan harga pokok produks bawang putih menjadi sangat penting bagi petani, karena harga merupakan salah satu penentu keberhasilan suatu usaha yang akan menentukan seberapa besar keuntungan yang diperoleh petani atas penjualan produknya. Tujuan penelitian adalah mengetahui harga pokok produksi dan besar keuntungan yang diperoleh petani bawang putih di desa Fatuneno Kabupaten Timor Tengah Utara selama melakukan kegiatan usahatani.

\section{Metode}

Penelitian ini dilaksanakan di Desa Fatuneno Kecamatan Miomaffo Bara Kabupaten Timor Tengah Utara karena Desa Fatuneno merupakan salah satu Desa penghasil bawang putih di Kecamatan Miomaffo Barat. Teknik penentuan sampel dilakukan secara purposive (sengaja) pada petani usahatani bawang putih di Desa Fatuneno, Kecamatan Miomaffo Barat, Kabupaten Timor Tengah Utara. Yang menjadi populasi dalam penelitian ini sebanyak 374 petani, dari jumlah populasi tersebut diambil 37 responden untuk dijadikan sampel. Analisis data menggunakan analisis deskriptif kuantitatif.

Mulyadi (2010) metode penentuan harga pokok produksi adalah cara memperhitungkan unsur-unsur biaya ke dalam harga pokok produksi. Dalam memperhitungkan unsur-unsur biaya ke dalam harga pokok produksi, terdapa dua pendekatan : full costing dan variable costing. Full costing adalah metode penentuan harga pokok produk yang memperhitungkan semua unsur biaya produksi yang terdiri dari biaya bahan baku, biaya tenaga kerja langsung, dan biaya overhead pabrik, baik yang bersifat variabel maupun tetap.

\section{Hasil dan Pembahasan}

\section{Gambaran Umum Lokasi Penelitian}

Desa Fatuneno adalah salah satu desa yang terletak di Kecamatan Miomaffo Barat Kabupaten Timor Tengah Utara. Desa Fatuneno adalah daerah zona iklim dingin yang berada pada ketinggian 2.500 Mdpl. Luas wilayah Desa Fatuneno adalah $2.500 \mathrm{Km}^{2}$ dengan batas wilayah sebagai berikut :

a. Sebelah Utara berbatasan dengan wilayah Desa Saenam

b. Sebelah Selatan berbatasan dengan wilayah Desa Satab

c. Sebelah Timur berbatasan dengan wilayah Desa Eban

d. Sebelah Barat berbatasan dengan wilayah Desa Noepesu

Penduduk Desa Fatuneno sesuai dengan hasil registrasi penduduk tahun 2019 berjumlah 1.437 jiwa dengan 374 kepala keluarga tani.

\section{a. Karakteristik Responden}

Karakteristik petani responden pada penelitian ini dirincikan oleh umur, jenis kelamin, pendidikan terakhir, jumlah tanggungan keluarga, pengalaman usaha tani, dan luas lahan.

\section{b. Umur Petani Responden}

Umur petani merupakan salah satu faktor yang mempengaruhi tingkat kemampuan dalam mengolah usahataninya. Berdasarkan hasil penelitian di lokasi menunjukkan bahwa umur responden seperti yang terlihat pada tabel 1 .

Tabel 1. Umur Petani Responden di Desa Fatuneno Tahun 2018

\begin{tabular}{ccc}
\hline Umur (Tahun) & Jumlah (Orang) & Persentase (\%) \\
\hline $35-44$ & 12 & 32.43 \\
$45-54$ & 14 & 37.84 \\
$55-64$ & 11 & 29.73 \\
Total & 37 & 100 \\
\hline
\end{tabular}

Sumber: Data Primer Diolah.

Sesuai dengan UU No 13 Tahun 2003 tentang Ketenagakerjaan, tenaga kerja produktif berusia 15-64 tahun.Berdasarkan tabel 1 dapat diketahui bahwa kisaran umur petani dalam penelitian ini adalah 35-44 tahun berjumlah 12 orang dengan persentase $32.43 \%, 45-54$ tahun berjumlah 14 orang dengan persentase $37.84 \%$, dan 55-64 tahun berjumlah 11 orang dengan persentase $29.73 \%$. Hasi penelitian menunjukkan bahwa umur petani bawang putih di Desa Fatuneno 100 $\%$ tergolong usia produktif.

\section{c. Jenis Kelamin Petani Responden}

Identitas petani bawang putih di Desa Fatuneno Kecamatan Miomaffo Barat, dimana jenis kelamin penduduk dalam suatu wilayah merupakan alat yang digunakan untuk mengetahui kondisi sosial ekonomi penduduk dalam wilayah itu sendiri.

Tabel 2. Jenis Kelamin Petani Responden di Desa Fatuneno Tahun 2018

\begin{tabular}{ccc}
\hline Jenis Kelamin (L/P) & Jumlah (Orang) & Persentase (\%) \\
\hline L & 32 & 86.49 \\
P & 5 & 13.51 \\
Total & 37 & 100 \\
\hline
\end{tabular}

Sumber: Data Primer Diolah. 2019.

Berdasarkan hasil penelitian ditemukan bahwa jumlah petani laki-laki di Desa Fatuneno berjumlah 32 orang dengan jumlah persentase $86.49 \%$ sedangkan petani perempuan berjumlah 5 orang dengan persentase $13.51 \%$.Hal in 
menunjukan bahwa petani laki-laki lebih banyak dari jumlah petani perempuan di Desa Fatuneno.

\section{d. Pendidikan Terakhir Petani Responden}

Tingkat pendidikan merupakan faktor pendukung bagi petani dalam suatu wilayah. Semakin tinggi tingkat pendidikan seorang petani, maka petani tersebut dengan mudahnya menerima perubahan atau inovasi baru yang dialaminya.

Tabel 3. Tingkat Pendidikan PetaniResponden di Desa Fatuneno Tahun 2018

\begin{tabular}{ccc}
\hline Pendidikan & Jumlah (Orang) & Persentase (\%) \\
\hline SD & 23 & 62.16 \\
SLTP & 8 & 21.62 \\
SLTA & 6 & 16.22 \\
Total & 37 & 100 \\
\hline
\end{tabular}

Sumber: Data Primer Diolah. 2019.

Disimpulkan bahwa petani bawang putih di Desa Fatuneno yang hanyamenempuh jenjang pendidikan terakhir di tingkat Sekolah Dasar (SD) sebanyak 23 orang dengan persentase mencapai $62.16 \%$, diikuti tingkat pendidikan Sekolah Menengah Pertama (SLTP) berjumlah 8 orang dengan persentase $21.62 \%$, sementara tingkat pendidikan Sekolah Menengah Atas (SLTA) berjumlah 6 orang dengan persentase $16.22 \%$.

Berdasarkan hasil penelitian ditemukan bahwa petani bawang putih di Desa Fatuneno sebagian besar adalah lulusan Sekolah Dasar (SD). Hal ini dapat dilihat bahwa petani bawang putih di Desa Fatuneno dalam segi pendidikan terbilang kurang, sehingga petani lebih mengandalkan pengalaman pribadi dalam berusahatani yang lebih dominan praktek dari pada teori pertanian sehingga kurangnya teknologi yang diterapkan dalam usahatani bawang putih.

\section{e. Jumlah Tanggungan Keluarga Petani Responden}

Tanggungan keluarga merupakan suatu beban atau kewajiban seorang kepala keluarga dalam membiayai/memberi nafkah kepada anggota keluarganya karena kewajiban ini maka, seseorang mulai menjalankan usaha-usaha yang dapat memberi kontribusi kepada keluarga.Tanggungan keluarga petani responden bawang putih di Desa Fatuneno pun berbeda-beda.

Tabel 4. Jumlah Tanggungan Keluarga Petani Responden di Desa Fatuneno Tahun 2018

\begin{tabular}{ccc}
\hline Tanggungan (Orang) & Jumlah & Persentase (\%) \\
\hline 2 & 6 & 16.21 \\
3 & 15 & 40.54 \\
4 & 11 & 29.73 \\
5 & 3 & 8.11 \\
6 & 2 & 5.41 \\
Total & 37 & 100 \\
\hline
\end{tabular}

\section{Sumber: Data Primer Diolah. 2019.}

Berdasarkan tabel 4 petani bawang putih di Desa Fatuneno yang memiliki Tanggungan keluarga2orang sebanyak 6 responden dengan persentase $16.21 \%$, sedangkan petani yang memiliki tanggungan keluarga 3 orang sebanyak 15 responden dengan persentase mencapai $40.54 \%$, petani yang memiliki tanggungan keluarga 4 orang sebanyak 11 responden dengan persentase $29.73 \%$, petani yang memiliki tanggungan keluarga 5 orang sebanyak 3 responden dengan persentase $8.11 \%$, dan petani yang memiliki tanggungan keluarga 6 orang sebanyak 2 responden dengan persentase $5.41 \%$.

\section{f. Pengalaman Usahatani Petani Responden}

Pengalaman usahatani bawang putih yang dimiliki oleh petani untuk menguasai teknik budidaya dalam kegiatan usahatani bawang putih yang dijalankan.

Tabel 5. Pengalaman Usahatani Petani Responden di Desa Fatuneno Tahun 2018

\begin{tabular}{ccc}
\hline Pengalaman (Tahun) & Jumlah (Orang) & Persentase (\%) \\
\hline $15-24$ & 18 & 48.65 \\
$25-34$ & 13 & 35.14 \\
$35-44$ & 6 & 16.21 \\
Total & 37 & 100 \\
\hline
\end{tabular}

Sumber: Data Primer Diolah. 2019.

Dari data diatas dapat disimpulkan bahwa petani bawang putih di Desa Fatuneno yang memiliki pengalaman berusahatani bawang putih 15-24 tahun berjumlah 18 orang dengan persentase $48.65 \%$, sedangkan yang memiliki pengalaman usahatani bawang putih 25-34 tahun berjumlah 13 orang dengan persentase $35.14 \%$, dan petani bawang putih yang memiliki pengalaman berusahatani 35-44 tahun berjumlah 6 orang dengan persentase $16.21 \%$. Hal ini menunjukkan bahwa petani di desa Fatuneno memiliki pengalaman yang cukup lama dalam berusahatani bawang putih dan akan melakukan kebiasaan yang lama berdasarkan panjangnya pengalaman usahatani.
Luas Lahan Petani Responden

Tabel 6. Luas Lahan Petani Responden di Desa Fatuneno Tahun 2018

\begin{tabular}{ccc}
\hline Luas Lahan (Are) & Jumlah (Orang) & Persentase (\%) \\
\hline $10-24$ & 27 & 72.97 \\
$25-34$ & 8 & 21.62 \\
$35-44$ & 2 & 5.41 \\
Total & 37 & 100
\end{tabular}

Sumber: Data Primer Diolah. 2019.

Dari tabel diatas dapat di simpulkan bahwa petani bawang putih di Desa Fatuneno sebagian besar memiliki luas lahan yang berkisar antara 10-24 are yang berjumlah 27 orang dengan persentase $72.97 \%$.

\section{g. Gambaran Umum Usahatani Bawang Putih}

Kegiatan usahatani bawang putih di Desa Fatuneno dilakukan dengan beberapa proses yakni: Pengolahan Lahan, Persiapan bibit, Penanaman, Pemeliharaan, Panen, Pasca Panen dan Pemasaran.

1. Pengolahan lahan dilakukan oleh tenaga kerja pria maupun wanita yaitu dengan cara tanah dibalik menggunakan linggis kemudian diratakan yang bertujuan untuk memperbaiki struktur tanah menjadi lebih gembur (remah). Disamping itu, sirkulasi udara dalam tanah akan lebih baik, mematikan cendawan dan telur-telur insekta yang terangkat ke permukaan tanah karena panas matahari. Pada kondisi tanah gembur, akan memudahkan perkembangan akar tanaman bawang putih lebih sempurna, sehingga tanaman akan tumbuh subur.

2. Pemakaian bibit/benih unggul dapat meningkatkan produksi. Berdasarkan hasil penelitian bibit yang digunakan adalah varietas lokal dari hasil panen sebelumnya. Bibit yang digunakan prtani usahatani bawang putih dalam 1 musim tanam tahun 2018 dari 37 responden sebanyak $2020 \mathrm{~kg}$

3. Penanaman biasa dilakukan pada bulan Mei dengan cara sehari sebelum tanam bawang putih yang masih berupa umbi kemudian dikupas, dipipil/dipecah-pecah menjadi beberapa siung kemudian ditanam pada lubang tanam yang dibuat dengan tugal sebanyak 1 siung setiap lubang. Jarak tanam yang dipakai rata-rata $15 \mathrm{~cm} \times 10 \mathrm{~cm}$.

4. Penyiangan pertama dilakukan pada saat tanaman berumur 2-3 minggu setelah tanam dengan menggunakan alat tofa (tajak), sekaligus bertujuan untuk menggemburkan tanah. Penyiangan berikutnya disesuaikan dengan keadaan pertumbuhan rumput/gulma. Masyarakat jarang bahkan tidak biasa menggunakan pupuk, baik pupuk organik maupun anorganik/kimia. Hal in disebabkan kurangnya pengetahuan petani manfaat dari penggunaan pupuk bagi tanaman. Petani beranggapan bahwa lahan yang diusahakan masih subur. Pengairan usahatani bawang putih tidak dilakukan secara intensif, karena penanamannya dilakukan diakhir musim hujan sehingga pengairan dilakukan secara alami dengan memanfaatkan sisa curah hujan. Apabila terjadi serangan hama/ penyakit pada tanaman bawang putih, petani kurang tanggap/cepat berupaya untuk mengendalikannya. Hal ini disebabkan beberapa faktor antaralain salah satunya karena petani tidak tahu apa jenis hama/penyakitnya dan bagaimana cara mengendalikannya.

5. Pemanenan dilakukan setelah mencapai masa umur panen 85-100 hari setelah tanam yang ditandai dengan mengeringnya batang daun. Biasanya petani memanen dengan cara dicabut langsung maupun dicungkil pada tanah yang agak berat, kemudian dikumpulkan sebelum dipisahkan dari batang daunnya setelah terkumpul dibersihkan dengan cara dipotong batang daunnya dan kotoran lainnya.

6. Pasca panen

Setelah panen, hasil panen di masukkan kedalam karung plastikkemudian pengangkutan hasil panen dari lokasi ke rumah bisanya dilakukan dengan menggunakan tenaga manusia. Hal ini dikarenakan lokasi panennya tidak jauh dari rumah. Penjemuran dilakukan dengan cara alami memanfaatkan panas sinar matahari langsung yaitu bawang putih hasil panen dihamburkan di atas bentangan alas terpal selama beberapa hari sampai kering. Bawang putih yang sudah kering kemudian dimasukkan ke dalam karung goni/plastik dan disimpan di dalam ruangan rumah atau di atas loteng dapur.

7. Pemasaran

Hasil produksi bawang putih dari masing-masing petani berbeda-beda, hal ini terjadi karena luas lahan usahatani bawang putih juga berbeda-beda, sehingga berpengaruh pada pendapatan petani juga berbeda. Selain itu juga salah satu faktor yang membedakan pendapatan petani adalah harga yang tidak sama, hal ini terjdi karena belum ada kesamaan harga antara petan yang satu dengan petani yang lainnya. Harga penjualan bawang putih di Desa Fatuneno berkisar antara Rp. 30.000 sampai Rp.50.000 per kilogram. Petani biasa menjual hasil produksinya langsung kepada tengkulak. Tengkulak/pedagang datang dilokasi terjadi kesepakatan harga dengan petani maka produk di jual atau dengan cara dijual langsung ke pasar.

\section{Harga Pokok Produksi}

Penghitungan harga pokok produksi adalah untuk mengetahui besarnya biaya produksi yang dikeluarkan dalam memproduksi suatu barang (Bawang Putih) yang dapat dihitung menggunakan metode full costing. 
Biaya Produksi yang digunakan dalam usahatani bawang putih meliputi: 1. Biaya Bahan Baku

Biaya bahan baku adalah bahan yang merupakan unsur paling pokok dalam proses produksi dan dapat langsung dibebankan kepada harga pokok barang yang diproduksi. Bahan baku yang digunakan petani selama proses produksi usahatani bawang putih adalah : Bibit, bibit yang digunakan petani usahatani bawang putih dalam 1 musim tanam tahun 2018 dari 37 responden sebanyak $2020 \mathrm{~kg}$ dengan harga bawang putih sebesar Rp.30.000/Kg, sehingga total biaya bibit dari 37 responden sebesar Rp. 60.600 .000 .

2. Biaya Tenaga Kerja

Untuk tenaga kerja dilokasi penelitian berasal dari tenaga kerja dalam keluarga yang merupakan sumbangan dalam keluarga pada produksi secara keseluruhan dan tidak pernah di nilai dengan uang (upah tenaga kerja).

3. Biaya Overhead

Biaya overhead adalah unsur biaya produksi selain biaya bahan baku langsung dan biaya tenaga kerja langsung yang dikeluarkan selama proses produksi. Biaya overhead dibagi menjadi dua bagian, yaitu: Biaya Overhead tetap dan biaya overhead variabel.

a. Biaya Overhead Tetap

Yang termasuk dalam biaya overhead tetap adalah biaya pajak dan biaya penyusutan peralatan.

1. Pajak merupakan bagian dari biaya tetap yang diperoleh dari luasan lahan yang digunakan dalam melakukan usahatani bawang putih. Besar pajak untuk 37 responden sebesar Rp. 713.000, dengan rata-rata Rp. 19.270.

2. Penyusutan alat merupakan salah satu biaya-biaya yang diperhitungkan dalam menganalisis usahatani. Biaya penyusutan alat dikategorikan biaya yang diperhitungkan karena petani sampel menggunakan alat-alat yang telah mereka beli pada musim tanam sebelumnya dan memiliki umur ekonomi sampai bertahun-tahun. Biaya penyusutan alat diperoleh dari nilai investasi alat dikurangi dengan nilai sisa dibagi dengan umur ekonomis dari alat yang digunakan tersebut. Total biaya penyusutan alat yang dikenakan petani sampel pada penelitian ini sebesar Rp. 22.282.149 dengan rata-rata biaya penyusutan peralatan sebesar Rp. 602.220 .

b. Biaya Overhead Variabel

Yang termasuk biaya overhead variabel adalah biaya pengangkutan sebesar 1.285.000, dan biaya karung plastik sebesar Rp. 456.000, sehingga total biaya Overhead variabel yang dikeluarkan petani adalah sebesar Rp. 1.741.000dengan total rata-rata sebesar Rp. 47.054

Harga Pokok Produksi Usahatani Bawang Putih Pada Luas Lahan 10-14 are di Desa Fatuneno

Tabel 7. Rerata Penggunaan Tenaga Kerja (HKO) Dan Biaya Produksi Usahatani Bawang Putih Pada Luas Lahan 10-14 Are di Desa Fatuneno

\begin{tabular}{|c|c|c|c|}
\hline $\begin{array}{l}\text { Kegiatan } \\
\text { Usahatani }\end{array}$ & $\begin{array}{l}\text { Rerata } \\
\mathrm{HKO} / \text { ha }\end{array}$ & $\begin{array}{c}\text { Keterangan } \\
\text { Biaya }\end{array}$ & $\begin{array}{c}\text { Rerata } \\
\text { Biaya }\end{array}$ \\
\hline Pengolahan Lahan : & & Biaya Bahan Baku & \\
\hline Pembersihan Lahan & 85,5 & Bibit $30,635 \mathrm{Kg}$ & 918.750 \\
\hline Pembuatan Bedeng & 437,9 & Biaya Overhead Tetap & \\
\hline Penanaman & 257,9 & Biaya Pajak & 13.625 \\
\hline $\begin{array}{l}\text { Pemeliharaan } \\
\text { Panen }\end{array}$ & 198 & $\begin{array}{l}\text { Biaya Peny. Peralatan } \\
\text { Biaya Overhead Variabel }\end{array}$ & 445.223 \\
\hline \multirow[t]{3}{*}{ Pasca Panen } & 343,6 & Biaya Pengangkutan & 26.250 \\
\hline & 465 & Biaya Karung Plastik & $\begin{array}{c}10.000+ \\
1.413 .848\end{array}$ \\
\hline & & Produksi & $69,625 \mathrm{~kg}$ \\
\hline
\end{tabular}

\begin{tabular}{lrr}
\hline Total & $1,787.9$ & Harga pokok produksi \\
\hline
\end{tabular}

Sumber: Data Primer Diolah. 2019.

Pada tabel 7 menunjukkan bahwa harga pokok produksi yang dikeluarkan petani pada luas lahan 10-14 are sebesar Rp. 20.307. Dalam penghitungan harga pokok produksi ini tidak dihitung biaya tenaga kerja karena tenaga kerja dilokasi penelitian berasal dari tenaga kerja dalam keluarga yang merupakan sumbangan dalam keluarga pada produksi secara keseluruhan dan tidak pernah di nilai dengan uang (upah tenaga kerja). Jika petani menggunakan tenaga kerja luar keluarga maka biaya/upah yang dikeluarkan petani untuk membayar tenaga kerja mulai dari kegiatan pembersihan lahan, pembuatan bedeng, penanaman, pemeliharaan, panen, dan pasca panen sebesar Rp. 4.084.538, sehingga harga pokok produksi yang akan dikeluarkan sebesar Rp. 78.971.

\section{Harga Pokok Produksi Usahatani Bawang Putih Pada Luas Lahan 15-19 are di Desa Fatuneno}

Pada tabel 8 menunjukkan bahwa harga pokok produksi yang dikeluarkan petani pada luas lahan 15-19 are sebesar Rp. 18.685. Dalam penghitungan harga pokok produksi ini tidak dihitung biaya tenaga kerja karena tenaga kerja dilokasi penelitian berasal dari tenaga kerja dalam keluarga yang merupakan sumbangan dalam keluarga pada produksi secara keseluruhan dan tidak pernah dinilai dengan uang (upah tenaga kerja). Jika petani menggunakan tenaga kerja luar keluarga maka biaya/upah yang dikeluarkan petani untuk membayar tenaga kerja mulai dari kegiatan pembersihan lahan, pembuatan bedeng, penanaman, pemeliharaan, panen, dan pasca panen sebesar Rp.3.489.636, sehingga harga pokok produksi yang akan dikeluarkan sebesar Rp.53.934.

Tabel 8. Rerata Penggunaan Tenaga Kerja (HKO) Dan Biaya Produksi Usahatani Bawang Putih Pada Luas Lahan 15-19 Are di Desa Fatuneno

\begin{tabular}{|c|c|c|c|}
\hline $\begin{array}{l}\text { Kegiatan } \\
\text { Usahatani }\end{array}$ & $\begin{array}{c}\text { Rerata } \\
\mathrm{HKO} / \mathrm{ha}\end{array}$ & $\begin{array}{c}\text { Keterangan } \\
\text { Biaya }\end{array}$ & $\begin{array}{c}\text { Rerata } \\
\text { Biaya }\end{array}$ \\
\hline Pengolahan & & Biaya Bahan Baku & \\
\hline Pembersihan Lahan & 53,93 & Bibit $45 \mathrm{Kg}$ & 1.350 .000 \\
\hline Pembuatan Bedeng & 223,8 & Biaya Overhead Tetap & \\
\hline Penanaman & 166,67 & Biaya Pajak & 14.167 \\
\hline Pemeliharaan & 137,8 & $\begin{array}{l}\text { Biaya Peny. Peralatan } \\
\text { Biaya Overhead Variabel }\end{array}$ & 452.342 \\
\hline Panen & 204,27 & Biaya Pengangkutan & 23.333 \\
\hline \multirow[t]{2}{*}{ Pasca Panen } & 323,8 & Biaya Karung Plastik & $\begin{array}{c}10.000+ \\
1.849 .842\end{array}$ \\
\hline & & Produksi & $99 \mathrm{~kg}$ : \\
\hline Total & $1,110.27$ & Harga pokok produksi & 18.685 \\
\hline
\end{tabular}

Harga Pokok Produksi Usahatani Bawang Putih Pada Luas Lahan 20-24 are di Desa Fatuneno

Tabel 9. Rerata Penggunaan Tenaga Kerja (HKO) Dan Biaya Produksi Usahatani Bawang Putih Pada Luas Lahan 20-24 Are di Desa Fatuneno

\begin{tabular}{|c|c|c|c|}
\hline $\begin{array}{l}\text { Kegiatan } \\
\text { Usahatani }\end{array}$ & $\begin{array}{l}\text { Rerata } \\
\mathrm{HKO} / \mathrm{ha}\end{array}$ & $\begin{array}{l}\text { Keterangan } \\
\text { Biaya }\end{array}$ & $\begin{array}{l}\text { Rerata } \\
\text { Biaya }\end{array}$ \\
\hline Pengolahan & & Biaya Bahan Baku & \\
\hline Lahan : & 46,3 & Bibit $55,83 \mathrm{Kg}$ & 1.675 .000 \\
\hline Pembersihan & 226,45 & Biaya Overhead Tetap & \\
\hline Lahan & & Biaya Pajak & 23.000 \\
\hline Pembuatan & 171,9 & Biaya Peny. Peralatan & 582.222 \\
\hline Bedeng & & Biaya Overhead Variabel & \\
\hline Penanaman & 165,35 & Biaya Pengangkutan & 29.583 \\
\hline Pemeliharaan & & Biaya Karung Plastik & $10.000+$ \\
\hline Panen & 250,25 & & 2.320 .722 \\
\hline Pasca Panen & 351,45 & Produksi & 138,16 : \\
\hline Total & $1,211.7$ & Harga pokok produksi & 16.797 \\
\hline
\end{tabular}

Pada tabel 9 menunjukkan bahwa harga pokok produksi yang dikeluarkan petani pada luas lahan 20-24 are sebesar Rp. 16.797. Dalam penghitungan harga pokok produksi ini tidak dihitung biaya tenaga kerja karena tenaga kerja dilokasi penelitian berasal dari tenaga kerja dalam keluarga yang merupakan sumbangan dalam keluarga pada produksi secara keseluruhan dan tidak pernah di nilai dengan uang (upah tenaga kerja). Jika petani menggunakan tenaga kerja luar keluarga maka biaya/upah yang dikeluarkan petani untuk membayar tenaga kerja mulai dari kegiatan pembersihan lahan, pembuatan bedeng, penanaman, pemeliharaan, panen, dan pasca panen sebesar Rp. 4.992.019, sehingga harga pokok produksi yang akan dikeluarkan sebesar Rp. 52.930 .

Harga Pokok Produksi Usahatani Bawang Putih Pada Luas Lahan 25-29 are di Desa Fatuneno

Tabel 10. Rerata Penggunaan Tenaga Kerja (HKO) Dan Biaya Produksi Usahatani Bawang Putih Pada Luas Lahan 25-29 Are di Desa Fatuneno

\begin{tabular}{|c|c|c|c|}
\hline $\begin{array}{l}\text { Kegiatan } \\
\text { Usahatani }\end{array}$ & $\begin{array}{c}\text { Rerata } \\
\mathrm{HKO} / \mathrm{ha}\end{array}$ & $\begin{array}{l}\text { Keterangan } \\
\text { Biaya }\end{array}$ & $\begin{array}{c}\text { Rerata } \\
\text { Biaya }\end{array}$ \\
\hline Pengolahan & & Biaya Bahan Baku & \\
\hline Lahan & 39,16 & Bibit $71,66 \mathrm{Kg}$ & 2.150 .000 \\
\hline Pembersihan & 158,76 & Biaya Overhead Tetap & \\
\hline Lahan & 116,76 & Biaya Pajak & 22.667 \\
\hline Pembuatan & 116 & Biaya Peny. Peralatan & 728.130 \\
\hline Bedeng & 217,16 & Biaya Overhead Variabel & \\
\hline Penanaman & 225,92 & Biaya Pengangkutan & 58.333 \\
\hline Pemeliharaan & & Biaya Karung Plastik & $17.000+$ \\
\hline Panen & & & 2.976 .130 \\
\hline Pasca Panen & & Produksi & $172,33 \mathrm{~kg}$ \\
\hline Total & 873.76 & Harga pokok produksi & 17.270 \\
\hline
\end{tabular}

Pada tabel 10 menunjukkan bahwa harga pokok produksi yang dikeluarkan petani pada luas lahan 25-29 are sebesar Rp.17.270. Dalam penghitungan harga pokok produksi ini tidak dihitung biaya tenaga kerja karena tenaga kerja dilokasi penelitian berasal dari tenaga kerja dalam keluarga yang merupakan sumbangan dalam keluarga pada produksi secara keseluruhan dan tidak pernah di nilai dengan uang (upah tenaga kerja). Jika petani menggunakan tenaga kerja luar keluarga maka biaya/upah yang dikeluarkan petani untuk membayar tenaga kerja mulai dari kegiatan pembersihan lahan, pembuatan bedeng, penanaman, pemeliharaan, panen, dan pasca panen sebesar Rp. 
4.587.132, sehingga harga pokok produksi yang akan dikeluarkan sebesar Rp. 43.888 .

\section{Harga Pokok Produksi Usahatani Bawang Putih Pada Luas Lahan 30-34 are di Desa Fatuneno}

Pada tabel 11 menunjukkan bahwa harga pokok produksi yang dikeluarkan petani pada luas lahan 30-34 are sebesar Rp.16.036. Dalam penghitungan harga pokok produksi ini tidak dihitung biaya tenaga kerja karena tenaga kerja dilokasi penelitian berasal dari tenaga kerja dalam keluarga yang merupakan sumbangan dalam keluarga pada produksi secara keseluruhan dan tidak pernah di nilai dengan uang (upah tenaga kerja). Jika petani menggunakan tenaga kerja luar keluarga maka biaya/upah yang dikeluarkan petani untuk membayar tenaga kerja mulai dari kegiatan pembersihan lahan, pembuatan bedeng, penanaman, pemeliharaan, panen, dan pasca panen sebesar Rp. 5.289.028, sehingga harga pokok produksi yang akan dikeluarkan sebesar Rp. 40.751 .

Tabel 11. Rerata Penggunaan Tenaga Kerja (HKO) Dan Biaya ProduksiUsahatani Bawang Putih Pada Luas Lahan 30-34 Are di Desa Fatuneno

\begin{tabular}{|c|c|c|c|}
\hline $\begin{array}{l}\text { Kegiatan } \\
\text { Usahatani }\end{array}$ & $\begin{array}{l}\text { Rerata } \\
\mathrm{HKO} / \mathrm{ha}\end{array}$ & $\begin{array}{c}\text { Keterangan } \\
\text { Biaya }\end{array}$ & $\begin{array}{l}\text { Rerata } \\
\text { Biaya }\end{array}$ \\
\hline Pengolahan Lahan & & Biaya Bahan Baku & \\
\hline Pembersihan Lahan & 34,93 & Bibit $55 \mathrm{Kg}$ & 2.400 .000 \\
\hline Pembuatan Bedeng & 157,5 & Biaya Overhead Tetap & \\
\hline Penanaman & 96,2 & Biaya Pajak & 15.333 \\
\hline Pemeliharaan & 121,9 & Biaya Peny. Peralatan & 957.020 \\
\hline Panen & 208,9 & BiayaOverhead Variabel & \\
\hline \multirow{3}{*}{ Pasca Panen } & 210,17 & Biaya Pengangkutan & 40.000 \\
\hline & & Biaya Karung Plastik & $\begin{array}{c}19.333+ \\
3.431 .686\end{array}$ \\
\hline & & Produksi & $214 \mathrm{~kg}$ : \\
\hline Total & 829,6 & Harga pokok produksi & 16.036 \\
\hline
\end{tabular}

Sumber: Data Primer Diolah. 2019.

\section{Harga Pokok Produksi Usahatani Bawang Putih Pada Luas Lahan 35-39} are di Desa Fatuneno

Tabel 12 menunjukkan bahwa harga pokok produksi yang dikeluarkan petani pada luas lahan 35-39 are sebesar Rp.13.242. Dalam penghitungan harga pokok produksi ini tidak dihitung biaya tenaga kerja karena tenaga kerja dilokasi penelitian berasal dari tenaga kerja dalam keluarga yang merupakan sumbangan dalam keluarga pada produksi secara keseluruhan dan tidak pernah di nilai dengan uang (upah tenaga kerja). Jika petani menggunakan tenaga kerja luar keluarga maka biaya/upah yang dikeluarkan petani untuk membayar tenaga kerja mulai dari kegiatan pembersihan lahan, pembuatan bedeng, penanaman, pemeliharaan, panen, dan pasca panen sebesar Rp. 4.099.965, sehingga harga pokok produksi yang akan dikeluarkan sebesar Rp. 28.921.

Tabel 12. Rerata Penggunaan Tenaga Kerja (HKO) Dan Biaya Produksi Usahatani Bawang Putih Pada Luas Lahan 35-39 Are di Desa Fatuneno

\begin{tabular}{lclc}
\hline $\begin{array}{l}\text { Kegiatan } \\
\text { Usahatani }\end{array}$ & $\begin{array}{c}\text { Rerata } \\
\text { HKO/ha }\end{array}$ & $\begin{array}{l}\text { Keterangan } \\
\text { Biaya }\end{array}$ & $\begin{array}{c}\text { Rerata } \\
\text { Biaya }\end{array}$ \\
\hline $\begin{array}{l}\text { Pengolahan Lahan : } \\
\text { Pembersihan Lahan }\end{array}$ & 16,31 & Biaya Bahan Baku & \\
Pembuatan Bedeng & 97,97 & Bibit 82,5Kg & 2.475 .000 \\
Penanaman & 78,37 & Biaya Pajak & \\
Pemeliharaan & 71,83 & Biaya Peny. Peralatan & 25.000 \\
Panen & 132,26 & Biaya Overhead & 889.905 \\
Pasca Panen & 181,23 & Variabel & 55.000 \\
& & Biaya Pengangkutan & $18.000+$ \\
& & Biaya Karung Plastik & 3.462 .950 \\
& & Produksi & $261,5 \mathrm{~kg}$ \\
\hline Total & 577.97 & Harga pokok produksi & 13.242 \\
\hline
\end{tabular}

\section{Sumber: Data Primer Diolah. 2019.}

Pada tabel 13, Harga pokok produksi yang dikeluarkan petani responden usahatani bawang putih di desa fatuneno dapat dilihat bahwa semakin besar luas lahan yang digunakan petani maka harga pokok produksi yang dikeluarkan semakin kecil. Penggunaan tenaga kerja semakin efisien pada petani yang memiliki luas lahan yang lebih besar. Produktivitas lahan juga mempengaruhi harga pokok produksi usaha tani bawang putih di desa Fatuneno. Harga pokok produksi bawang putih yang dianalisis pada penelitian menunjukkan bahwa petani belum memiliki keuntungan.

Dalam penelitian harga pokok produksi usahatani bawang putih ini berbeda dengan Damayanti (2016), dimana penelitian harga pokok produksi usahatani cabai merah, petani sudah memiliki keuntungan dalam usahatani cabai merah.
Tabel 13. Harga Pokok Produksi Yang Dikeluarkan Petani Responden Usahatani Bawang Putih Di Desa Fatuneno Tahun 2018

\begin{tabular}{cc}
\hline Luas Lahan (Are) & Harga Pokok Produksi/Kg \\
\hline $10-14$ & 78.971 \\
$15-19$ & 53.934 \\
$20-24$ & 52.934 \\
$25-29$ & 43.888 \\
$30-34$ & 40.751 \\
$35-39$ & 28.291 \\
\hline Rata-rata & 59.754 \\
\hline
\end{tabular}

\section{Penerimaan, Pendapatan Dan Keuntungan \\ Penerimaan Usahatani Bawang Putih}

Penerimaan usahatani adalah perkalian antara produksi dan harga jual. Harga jual adalah harga transaksi antara produsen dan pembeli untuk setiap komoditas. Satuan yang digunakan seperti satuan yang lazim digunakan antar penjual/pembeli misalnya: kilogram $(\mathrm{kg})$.

Penerimaan dalam penelitian ini mengikuti prinsip Soekartawi (1995) dan satuan yang digunakan untuk usahatani bawang putih adalah kilogram $(\mathrm{kg})$ ditingkat petani dan harga yang ditetapkan sebesar Rp 30.000 per kilogramnya. Produksi usahatani bawang putih dalam 1 musim tanam dari 37 responden diperoleh sebesar $5008 \mathrm{~kg}$ dengan rata-rata $135 \mathrm{~kg}$.

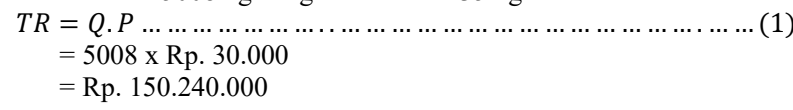

Berdasarkan hasil produksi bawang putih tersebut maka diperoleh penerimaan 37 responden petani usahatani bawang putih sebesar $\mathrm{Rp}$. 150.240.000 dengan rata-rata penerimaan responden sebesar Rp. 4.060 .541 per musim tanam

\section{Pendapatan Usahatani Bawang Putih}

Joesron, T.S dan Fathorrazi (2012), menjelaskan bahwa pendapatan usahatani adalah selisih antara total penerimaan dengan semua biaya yang dikeluarkan. Berdasarkan hasil perhitungan 37 responden petani bawang putih diperoleh total biaya sebesar $\mathrm{Rp}$. 85.336.149dengan rata-rata total biaya $\mathrm{Rp}$. 2.306.382 dan total penerimaan sebesar Rp. 150.240.000 dan rata-rata total penerimaan sebesar Rp. 4.060.541. Hasil perhitungan tersebut kemudian diinterpretasikan kedalam rumus pendapatan sehingga diperoleh total pendapatan dari 37 responden petani bawang putih sebesar Rp. 64.903.851 dengan rata-rata pendapatan sebesar Rp.1.754.158 per musim tanam.

Tabel 14. PendapatanUsahatani Bawang Putih Berdasarkan Luas Lahan Pada Petani Di Desa Fatuneno

\begin{tabular}{cc}
\hline Luas Lahan (Are) & Pendapatan \\
\hline $10-14$ & 674.902 \\
$15-19$ & 1.120 .158 \\
$20-24$ & 1.824 .278 \\
$25-29$ & 2.193 .870 \\
$30-34$ & 2.988 .313 \\
$35-39$ & 4.382 .095 \\
\hline Rata-rata & 2.636 .723
\end{tabular}

Pada tabel 14 menunjukkan bahwa rata-rata perolehan pendapatan usahatani bawang putih terbesar pada luas lahan 35-39 are dengan total rata-rata pendapatan sebesar Rp.4.382.095. Rata-rata pendapatan usaha tani di desa Fatuneno Rp. 125.558/are.

\section{Keuntungan Relative (R/C Ratio) Usahatani Bawang Putih}

R/C ratio adalah singkatan dari Return Cost ratio atau dikenal sebaga pembanding (nisbah) antara total penerimaan dengan total biaya. Total penerimaan dari 37 responden petani bawang putih di Desa Fatuneno sebesar Rp. 150.240.000 dengan rata-rata peneriman dari petani-petani tersebut adalah $\mathrm{Rp}$. 4.060.541, sedangkan total biaya yang dikeluarkan oleh petani dalam mengusahakan bawang puth sebesar Rp. 85.336.149 dengan rata-rata pengeluaran biaya sebesar Rp. 2.306 .382 per musim tanam

$$
\begin{aligned}
\text { R/CRatio }= & \frac{\mathrm{TR}}{\mathrm{TC}} \ldots \ldots \ldots \ldots \\
= & 150.240 .000 \\
& 85.336 .149 \\
= & 1,76
\end{aligned}
$$

Perbandingan antara total penerimaan dan biaya yang dikeluarkan 37 petani bawang putih di desa Fatuneno secara ekonomis menguntungkan karena nilai $\mathrm{R} / \mathrm{C}$ rasio yang diperoleh lebih besar dari 1 . 
Tabel 15. Penerimaan, R/C Ratio Dan Harga Pokok Produksi Berdasarkan Luas Lahan Pada Petani Bawang Putih Di Desa Fatuneno

\begin{tabular}{ccc}
\hline Luas Lahan (Are) & Penerimaan & R/C Ratio \\
\hline $10-14$ & 2.088 .750 & 1,48 \\
$15-19$ & 2.970 .000 & 1,60 \\
$20-24$ & 4.145 .000 & 2,80 \\
$25-29$ & 5.170 .000 & 2,74 \\
$30-34$ & 6.420 .000 & 2,87 \\
$35-39$ & 7.845 .000 & 2,27 \\
\hline Rata-rata & 5.727 .750 & 1,76 \\
\hline
\end{tabular}

Pada tabel 15 menunjukkan bahwa rata-rata penerimaan dan R/C Ratio terbesar pada luas lahan 35-39 are dengan total rata-rata penerimaan sebesar Rp.7.845.000 dan R/C Ratio sebesar 2,27. Rata-rata penerimaan oleh petani di desa Fatuneno sebesar Rp. 272.750/are. Rata-rata R/C rasio petani di desa Fatuneno sebesar 1,76.

\section{Simpulan}

Berdasarkan hasil penelitian : (1). Harga pokok produksi petani bawang putih menggunakan metode full costing yang dikeluarkan di desa Fatuneno dengan luas lahan terkecil sebesar Rp.78.791/kg dan luas lahan terbesar sebesar Rp. 28.921/kg dengan rata-rata harga pokok produksi sebesar Rp. 59.754/kg. (2). $R / C$ rasio usahatani bawang putih di desa Fatuneno dengan luas lahan terkecil sebesar 1,48 dan luas lahan terbesar 2,27, dengan rata-rata $\mathrm{R} / \mathrm{C}$ rasio sebesar 1,76.

\section{Pustaka}

Badan Pusat Statistik Kabupaten Timor Tengah Utara. 2017. Timor Tengah Utara dalam Angka. Badan Pusat Statistik. Kefamenanu.

Carter, William K. 2009. Akuntansi Biaya. Edisi Empat Belas. Salemba Empat, Jakarta

Damayanti, U., \& Herdian, D. (2016). Analisis Harga pokok Dan Keuntungan Usahatani Cabai Merah Besar (Capsicum Annuum L) Di Desa Talang Buluh Kecamatan Talang Kelapa Kabupaten Banyuasin.Jurnal TriAgro, 1(2).

Joesron, T. S. Fathorrozi.(2012). Teori Ekonomi Mikro. Jakarta: Salemba Empat. Mulyadi . 2010. Akuntansi Biaya. UPP-STIM-YKPN, Yogyakarta.

Samryn, L. M. (2002). Akuntansi Manajerial. Edisi Pertama, Raja Grafindo Persada.

Soekartawi. 1995. Analisis Usahatani. Universitas Indonesia. Jakarta. 